\title{
NOMINATION SUBMIISSIONS
}

The Council of the American Meteorological Society invites members of the AMS to submit nominations for consideration by the committees listed below. The names of all individuals nominated, together with background data on the individuals, should be sent to the appropriate committee (care of American Meteorological Society, 45 Beacon St., Boston, MA 021083693; please note that deadlines differ). Nominations for Society awards, fellows, and lectures must be submitted on the appropriate forms, which are available on the AMS Web site or by request from AMS Headquarters. It is encouraged that three one-page letters of endorsement accompany any nominations.

The specifications for all awards are set forth on the AMS Web site (www.ametsoc.org/aboutams/awardrecipients.html).

\section{SOCIETY AWARDS}

\section{AWARDS COMMITTEES}

The committees' function is to submit to the Council the names of individuals nominated for the Society's awards. The names of the nominees for awards remain on the awards committees' active list for three years. Nominations must be submitted before 1 May 2005 to the appropriate awards committee.

\section{ATMOSPHERIC RESEARCH AWARDS COMMITTEE}

- The Carl-Gustaf Rossby Research Medal

- The Jule G. Charney Award

- The Verner E. Suomi Award*

- The Clarence Leroy Meisinger Award

- The Henry G. Houghton Award

\section{OCEANOGRAPHIC RESEARCH AWARDS COMMITTEE}

- The Sverdrup Gold Medal

- The Henry Stommel Research Award

- The Verner E. Suomi Award*

\section{AWARDS OVERSIGHT COMMITTEE}

- The Charles Franklin Brooks Award for Outstanding Services to the Society

- The Cleveland Abbe Award for Distinguished Service to the Atmospheric Sciences by an Individual

- The Award for Outstanding Services to Meteorology by a Corporation

- Special Awards

\section{EDUCATION AND HUMAN RESOURCES COMMISSIONER}

- The Louis J. Battan Author's Award

- The Dr. Charles E. Anderson Award

- The Teaching Excellence Award

* Recommended by the Atmospheric Research Awards Committee in even-numbered years and by the Oceanographic Research Awards Committee in odd-numbered years.

\section{ADDITIONAL AWARDS}

Nominations must be submitted before 1 May 2005 to the appropriate committee.

\section{THE AWARD FOR OUTSTANDING SERVICE BY A WEATHER FORECASTER}

- The Charles L. Mitchell Award for long-term service by persons engaged in weather forecasting activities

- The Award for an Exceptional Specific Prediction

Submit documentation for these awards to the AMS Committee on Weather Analysis and Forecasting with a copy to the STAC Commissioner.

\section{THE FRANCIS W. REICHELDERFER AWARD}

Given for distinguished contributions to the provision of operational environmental services to the public. Submit documentation to the STAC Commissioner.

THE AWARD FOR OUTSTANDING CONTRIBUTION TO THE ADVANCE OF APPLIED METEOROLOGY

Submit documentation to the AMS Board of Private Sector Meteorology with a copy to the Professional Affairs Commissioner.

\section{THE AWARD FOR BROADCAST METEOROLOGY}

Submit documentation to the AMS Board of Broadcast Meteorology with a copy to the Professional Affairs Commissioner.

\section{THE AWARD FOR OUTSTANDING ACHIEVEMENT IN BIOMETEOROLOGY}

Submit documentation to the Committee on Biometeorology and Aerobiology with a copy to the STAC Commissioner.

\section{THE ROBERT LEVITON AWARD}

Submit documentation to the AMS Committee on Measurements with a copy to the STAC Commissioner.

\section{THE BANNER I. MILLER AWARD}

Submit documentation to the Committee on Tropical Meteorology and Tropical Cyclones with a copy to the STAC Commissioner. 


\section{NOMINATION SUBMIISSIONS}

\section{NOMTAUWC COMMITIEE}

The Committee's function is to submit to the Council the names of individuals for 1) the office of President-Elect for a term of one year starting at the close of the 86th Annual Meeting (January 2006), and 2) four positions on the Council for a term of three years starting at the close of the Annual Meeting. Nominations must be submitted prior to 1 April 2005 to the Nominating Committee.

\section{FELLOWS COMMITTEE}

The Committee's function is to submit to the Council the names of individuals for election to Fellow.

Article III, Section 6, of the AMS Constitution provides that those eligible for election to Fellow shall have made outstanding contributions to the atmospheric or related oceanic or hydrologic sciences or their applications during a substantial period of years. The names of nominees for Fellow remain on the Committee's active list for three years.

Fellow nominations must be submitted on the required form prior to 1 May 2005 to the Fellows Committee.

\section{LECTURER NOMINATIONS}

Nominations for the following four lectureships should be submitted on the required form before 1 October 2005 to the committee(s) shown below and the STAC Commissioner.

\section{THE ROBERT E. HORTON LECTURER IN HYDROLOGY}

Submit documentation to the Committee on Hydrology.

\section{THE BERNHARD HAURWITZ MEMORIAL LECTURER}

Submit documentation to the Atmospheric and Oceanic Fluid Dynamics, Middle Atmosphere, or Climate Variations Committees.

\section{THE REMOTE SENSING LECTURER}

Submit documentation to the Radar, Satellite, Laser, Atmospheric Radiation, or Measurements Committees.

\section{THE WALTER ORR ROBERTS LECTURER IN INTERDISCIPLINARY SCIENCES}

Submit documentation to the chairperson of any STAC committee.

\section{LOCAL CHAPTER OF THE YEAR AWARD}

Applications for the Local Chapter of the Year Award should be submitted on the required form before 1 May 2005 to the Local Chapter Affairs Committee.

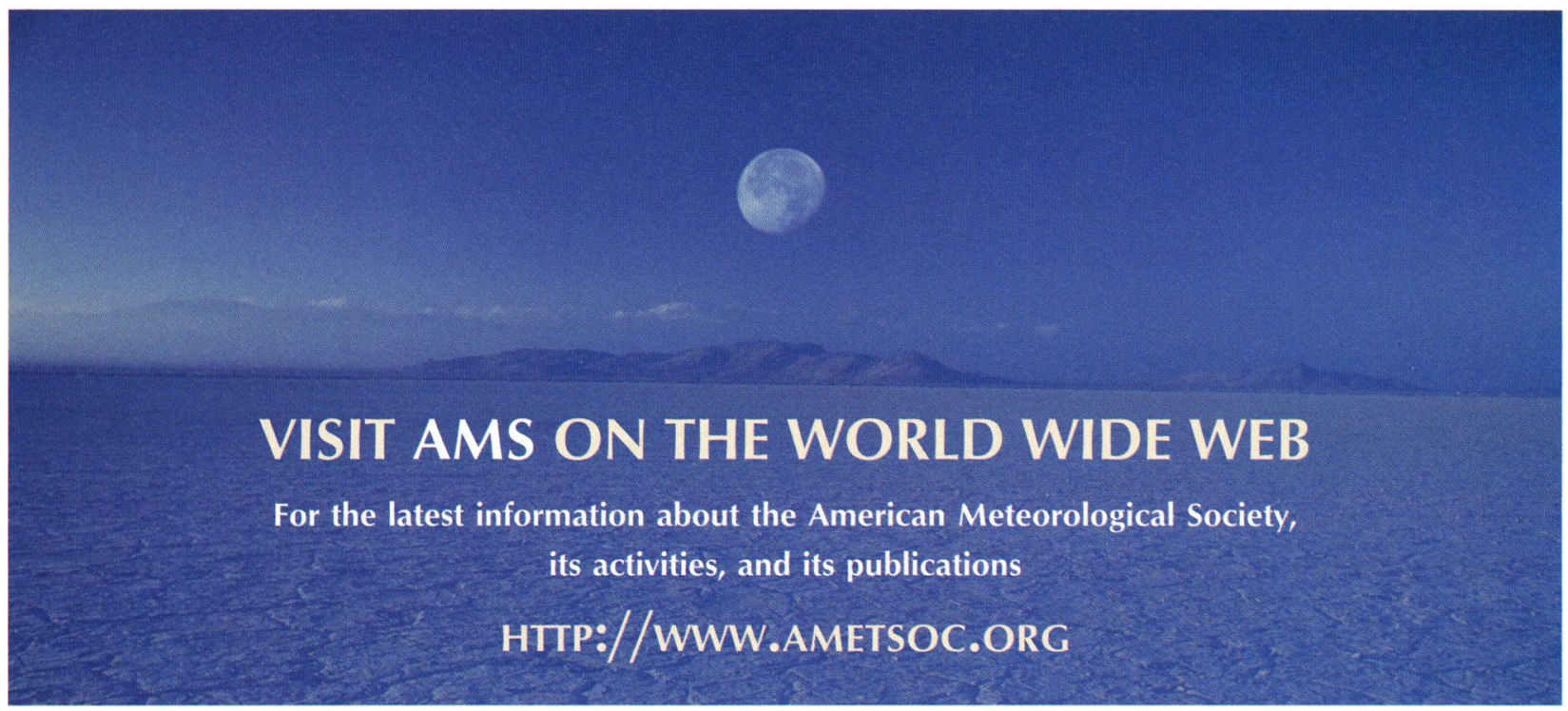

